\title{
Field Efficacy of Certain Bio-Pesticides against Chilli Thrips Scirtothrips dorsalis (HOOD) on Chilli (Capsicum annuum L.)
}

\author{
Rakesh Kumar Meena and Anoorag R. Tayde* \\ Department of Entomology, Naini Agriculture Institute, Sam Higginbottom University of \\ Agriculture, Technology and Sciences, Allahabad - 211 007, India \\ *Corresponding author
}

\section{A B S T R A C T}

\begin{tabular}{|l|}
\hline Ke y w o r d s \\
Efficacy, \\
Scirtothrips \\
dorsalis, \\
Biopesticides, \\
Chilli, Allahabad. \\
\hline Article Info \\
\hline $\begin{array}{l}\text { Accepted: } \\
\text { 26 May } 2017 \\
\text { Available Online: } \\
\text { 10 June } 2017\end{array}$ \\
\hline
\end{tabular}

Keywords

Efficacy, Scirtothrips dorsalis, Biopesticides, Article Info Accepted: 26 May 2017 10 June 2017

\begin{abstract}
A field experiment on the efficacy of certain biopesticides for control of chilli thrips, Scirtothrips dorsalis Hood conducted at the Central field, Sam Higginbottom University of Agriculture Technology and Sciences, Allahabad, Uttar Pradesh, India during July 2016 to November 2016. Results revealed that among the different treatments, Spinosad $(73.21 \%)$ proved to be the most effective treatments followed by Imidacloprid (67.58\%), Pongima oil (55.78\%), Neem oil $(55.64 \%)$, NSKE $(53.03 \%)$ and Garlic sap extract $(50.03 \%)$, whereas, Beauveria bassiana $(33.36 \%)$ was found to be least effective against this pest. The plots treated with Spinosad show highest $(272.33 \mathrm{q} / \mathrm{ha})$ yield was followed by Imidacloprid (250.88q/ha), Pongamia oil (192.62q/ha), Neem oil (185.70q/ha), NSKE (165.66q/ha) and Garlic sap extract (142.32q/ha), and Beauveria bassiana (133.80q/ha). Economics of different treatments showed appreciable Incremental Cost-Benefit Ratio obtained in case of Spinosad (1:11.36) followed by Imidacloprid (1:10.88), Pongima oil (1:8.19), Neem oil(1:7.92), NSKE (1:6.52) Garlic sap extract(1:5.69), Beauveria bassiana (1:5.30) as compared to control (1:3.74) respectively.
\end{abstract}

\section{Introduction}

Chilli (Capsicum annum L.) popularly known as 'mirch' in Hindi. It belongs to the family Solanaceae. Chilli is one of the important vegetable and commercial spice crops. Green fruits are a good source of vitamin A and $\mathrm{C}$ besides traditional use of chillies in vegetables, spices, sauces and pickles (Mondal et al., 2012). The pungency in chillies is due to crystalline volatile alkaloid 'Capsaicin'. The red color of chillies is due to the presence of pigment 'Capsanthin' (Choudhary et al., 2009). In India Andhra Pradesh is the major chilli growing state in the country, contributing 33 per cent of national production with an area of 2.35 lakh hectares (Reddy and Sreehari 2009). The area occupied in India is $14.5 \mathrm{~m}$ ha and the production is 8.2 lakhs or 0.8 million tons and Uttar Pradesh occupies about 1.8 thousand ha area and 1.7 thousand tons production respectively (Rai and Pandey, 2007). The area occupied in Allahabad region is 2455 ha and the production is 2993 tons (Kumar et al., 2012). These days use of botanicals is one of the most common and popular methods for its management. So, by using the botanicals having a novel mode of action with higher bioefficacy on insect control environment and mammals will be saved. Bioefficacy of biopesticides needs to be studied for formulating 
effective and economical management strategies of the chilli thrips in Allahabad region. Therefore, the present study was undertaken and the results obtained are discussed here.

\section{Materials and Methods}

The experiment was conducted during Kharif season 2016 at the Central Field of Sam Higginbottom University of Agriculture, Technology and Sciences Allahabad, Uttar Pradesh, India, in a randomised block design with eight treatments, using variety Suryamukhi in a plot size of $(2 \mathrm{~m} \times 1 \mathrm{~m})$ at a spacing of $(45 \times 30 \mathrm{~cm})$ with recommended package of practices excluding plant protection.

The spraying was done after the population reaching its ETL (5 thrips/plant). The observation of the pests was recorded from three tender leaves of five randomly selected plants from each net plot area and three leaves (top, middle, and bottom) from each plant were selected. The average percent reduction of pest population of all three sprays was worked out by using Henderson and Tilton's formula described as under:

Percent reduction $=100(1-\mathrm{Ta} \times \mathrm{Cb} / \mathrm{Tb} \times \mathrm{Ca})$

Where,

$\mathrm{Ta}=$ number of insects in treated plot after insecticide application.

$\mathrm{Tb}=$ number of insects in treated plot before insecticide application.

$\mathrm{Ca}=$ number of insects in untreated check after insecticide application.

$\mathrm{Cb}=$ number of insects in untreated plot check before insecticide application.
The percent reduction was transformed to angular values from which analysis of variance was calculated for determining the critical difference (CD) at 5 percent level of significance.

The data on thrips population thus converted to the percentage of mortality and were subjected to statistically analysis after arcsine transformation. The data on percentage reduction obtained are presented in table 1 (overall mean $1^{\text {st }} 2^{\text {nd }} 3^{\text {rd }}$ spray). The insecticide treatments include Spionsad, Imidacloprid, NSKE, Garlic sap extract, neem oil, Pongamia oil, Beauveria bassiana along with untreated control. The incidence of the chilli thrips was recorded from the five randomly selected plants. Observations were recorded one day before spray and $3^{\text {rd }}, 10^{\text {th }}$ days after spraying. Treatment wise yield of healthy marketable fruits was recorded at each picking, converted them in $\mathrm{Kg} / \mathrm{ha}$ and data thus obtained were statistically analyzed (steel and Torrie, 1980).Economics of different treatments were worked out based on yield and cost of treatments. The values of Insecticides cost-benefit ratio obtained for different treatments are furnished in table 2 .

\section{Results and Discussion}

The data presented in table 1 on percent population reduction of Scirtothrips dorsalis over control on first, second and third spray revealed that all the treatments were significantly superior to control. Among all the treatments Spinosad $0.015 \%$ recorded highest reduction of Scirtothrips dorsalis population i.e. $(71.21 \%)$ which was significantly superior to control followed by Imidacloprid $0.005 \%$ (67.58\%), Pongamia oil $4 \%(55.78 \%)$ Neem oil $2.5 \mathrm{ml} / 1$ (55.64\%), Garlic sap extract $10 \mathrm{~g} / \mathrm{Lit}$. (53.03\%), NSKE 5\% (50.03\%) and Beauveria bassiana $2 \mathrm{gm} / \mathrm{Lit}(33.36 \%)$ was least effective among all the treatments. The population reduction 
was recorded with Spinosad ranked first followed by imidacloprid. All the biopesticides significantly reduced thrips population over control. Spinosad was more effective in percentage reduction of thrips with 71.21 reductions over control similar finding made by Vanisree et al., (2013), Vijaya et al., (2016) and Seal et al., (2006) they reported that Spinosad was found most effective in reducing the population of Scirtothrips dorsalis as well as in increasing yield. Seal et al., also found that spinosad and imidacloprid most effective in reducing the density of Scirtothrips dorsalis. Tommasini et al., (2007) reported acrinathrin and spinosad proved to be most effective against thrips, particularly where a high relative abundance of thrips was present and this result also supported by Larral and Ripa (2007). Imidacloprid $0.005 \%$ was the next most effective treatment in percentage reduction of chilli with $67.58 \%$ reduction over control also reported by Patel et al., (2009) and Seal et al., (2006).

Table.1 Field efficacy of certain biopesticides against Chilli thrips (Scirtothrips dorsalis) on Chilli (Capsicum annuиm L.) during Kharif season, 2016 (Overall mean)

\begin{tabular}{|c|c|c|c|c|c|}
\hline \multirow[b]{2}{*}{$\begin{array}{l}\text { Treatment } \\
\text { No. }\end{array}$} & \multirow[b]{2}{*}{ Treatment } & \multicolumn{4}{|c|}{$\begin{array}{l}\text { \% Reduction over control population of Scirtothrips } \\
\text { dorsalis. }\end{array}$} \\
\hline & & $\begin{array}{l}1^{\text {st }} \quad \text { Spray } \\
\text { Mean }\end{array}$ & $\begin{array}{l}2^{\text {nd }} \text { spray } \\
\text { Mean }\end{array}$ & $\begin{array}{l}3^{\text {rd }} \quad \text { Spray } \\
\text { Mean }\end{array}$ & Overall Mean \\
\hline $\mathrm{T}_{1}$ & $\begin{array}{l}\text { Imidacloprid } \\
(0.005 \%)\end{array}$ & $\begin{array}{l}55.84 \\
\mathbf{( 4 8 . 3 5 )}\end{array}$ & $\begin{array}{l}70.25 \\
(\mathbf{5 6 . 9 5})\end{array}$ & $\begin{array}{l}76.67 \\
(\mathbf{6 1 . 1 2})\end{array}$ & $\begin{array}{l}67.58 \\
\mathbf{( 5 5 . 4 7 )}\end{array}$ \\
\hline $\mathrm{T}_{2}$ & $\begin{array}{l}\text { Spinosad } \\
(0.015 \%)\end{array}$ & $\begin{array}{l}60.84 \\
(\mathbf{5 1 . 2 6})\end{array}$ & $\begin{array}{l}71.56 \\
(\mathbf{5 7 . 7 7 )}\end{array}$ & $\begin{array}{l}81.24 \\
(64.33)\end{array}$ & $\begin{array}{l}71.21 \\
\mathbf{( 5 7 . 7 8 )}\end{array}$ \\
\hline $\mathrm{T}_{3}$ & $\begin{array}{l}\text { NSKE } \\
(5 \%)\end{array}$ & $\begin{array}{l}43.17 \\
\mathbf{( 4 1 . 1 7 )}\end{array}$ & $\begin{array}{l}54.55 \\
(\mathbf{4 7 . 6 1 )}\end{array}$ & $\begin{array}{l}53.24 \\
\mathbf{( 4 6 . 8 6 )}\end{array}$ & $\begin{array}{l}50.32 \\
\mathbf{( 4 5 . 1 8 )}\end{array}$ \\
\hline $\mathrm{T}_{4}$ & $\begin{array}{l}\text { Garlic sap } \\
\text { Extract } \\
(10 \mathrm{~g} / \mathrm{lit})\end{array}$ & $\begin{array}{l}42.17 \\
\mathbf{( 4 0 . 5 0 )}\end{array}$ & $\begin{array}{l}51.67 \\
\mathbf{( 4 5 . 9 5 )}\end{array}$ & $\begin{array}{l}65.27 \\
\mathbf{( 5 3 . 8 9 )}\end{array}$ & $\begin{array}{l}53.03 \\
\mathbf{( 4 6 . 7 8 )}\end{array}$ \\
\hline $\mathrm{T}_{5}$ & $\begin{array}{l}\text { Neem oil } \\
(2.5 \mathrm{ml})\end{array}$ & $\begin{array}{l}44.83 \\
\mathbf{( 4 2 . 0 3 )}\end{array}$ & $\begin{array}{l}56.71 \\
\mathbf{( 4 8 . 8 5 )}\end{array}$ & $\begin{array}{l}65.38 \\
\mathbf{( 5 3 . 9 6 )}\end{array}$ & $\begin{array}{l}55.64 \\
(\mathbf{4 8 . 2 8})\end{array}$ \\
\hline $\mathrm{T}_{6}$ & $\begin{array}{l}\text { Pongamia } \\
\text { Oil (4\%) }\end{array}$ & $\begin{array}{l}47.34 \\
(\mathbf{4 3 . 4 7 )}\end{array}$ & $\begin{array}{l}52.92 \\
(\mathbf{4 6 . 6 8 )}\end{array}$ & $\begin{array}{l}67.10 \\
\mathbf{( 5 5 . 0 0 )}\end{array}$ & $\begin{array}{l}55.78 \\
(48.38)\end{array}$ \\
\hline $\mathrm{T}_{7}$ & $\begin{array}{l}\text { Beauveria } \\
\text { Bassiana (2g/lit) }\end{array}$ & $\begin{array}{l}33.00 \\
\text { (35.06) }\end{array}$ & $\begin{array}{l}31.57 \\
\mathbf{( 3 4 . 1 9 )}\end{array}$ & $\begin{array}{l}35.53 \\
(\mathbf{3 6 . 5 9 )}\end{array}$ & $\begin{array}{l}33.36 \\
\mathbf{( 3 5 . 2 8 )}\end{array}$ \\
\hline \multirow[t]{4}{*}{$\mathrm{T}_{0}$} & Control & 0 & 0 & 0 & 0 \\
\hline & F-Test & $\mathrm{S}$ & $\mathrm{S}$ & $\mathrm{S}$ & $\mathrm{S}$ \\
\hline & S.Ed $( \pm)$ & 3.34 & 3.39 & 2.77 & 4.09 \\
\hline & C.D. $(P=0.05)$ & 7.09 & 7.19 & 5.89 & 8.67 \\
\hline
\end{tabular}

*Figures in parenthesis are arc sin transformed values. 
Table.2 Economics of cultivation

\begin{tabular}{|l|l|l|l|l|l|l|l|l|}
\hline $\begin{array}{l}\text { Tr. } \\
\text { No: }\end{array}$ & Treatment & $\begin{array}{l}\text { Yield } \\
\text { q/ha }\end{array}$ & $\begin{array}{l}\text { Total } \\
\text { cost of } \\
\text { yield in } \\
\text { Rs }\end{array}$ & $\begin{array}{l}\text { Common } \\
\text { cost in Rs }\end{array}$ & $\begin{array}{l}\text { Treat } \\
\text { ment } \\
\text { cost in } \\
\text { Rs }\end{array}$ & $\begin{array}{l}\text { Total } \\
\text { cost in } \\
\text { Rs }\end{array}$ & $\begin{array}{l}\text { Net } \\
\text { returns } \\
\text { in Rs }\end{array}$ & $\begin{array}{l}\text { C:B } \\
\text { ratio }\end{array}$ \\
\hline $\mathrm{T}_{1}$ & $\begin{array}{l}\text { Imidacloprid } \\
(0.005 \%)\end{array}$ & 250.88 & 376320 & 29885 & 1980 & 31865 & 344455 & $1: 10.80$ \\
\hline $\mathrm{T}_{2}$ & Spinosad (0.015\%) & 272.33 & 408495 & 29885 & 3150 & 33035 & 375460 & $1: 11.36$ \\
\hline $\mathrm{T}_{3}$ & NSKE (5\%) & 165.66 & 247500 & 29885 & 3000 & 32885 & 214615 & $1: 6.52$ \\
\hline $\mathrm{T}_{4}$ & $\begin{array}{l}\text { Garlic sap extract } \\
(10 \mathrm{~g} / \text { lit) }\end{array}$ & 142.32 & 213480 & 29885 & 1980 & 31865 & 181615 & $1: 5.69$ \\
\hline $\mathrm{T}_{5}$ & Neem oil (2.5ml/l) & 185.70 & 278550 & 29885 & 1500 & 31385 & 248665 & $1: 7.92$ \\
\hline $\mathrm{T}_{6}$ & Pongima oil (4\%) & 192.62 & 288930 & 29885 & 1560 & 31445 & 257545 & $1: 8.19$ \\
\hline $\mathrm{T}_{7}$ & $\begin{array}{l}\text { Beauvria bassiana } \\
(2 \mathrm{gm} / \mathrm{l})\end{array}$ & 133.80 & 200730 & 29885 & 1950 & 31835 & 168895 & $1: 5.30$ \\
\hline $\mathrm{T}_{0}$ & Untreated/Control & 94.5 & 141750 & 29885 & - & 29885 & 111865 & $1: 3.74$ \\
\hline
\end{tabular}

*Cost of yield Rs/q - 1500

The yields among the treatment were significant. The highest yield was recorded in Spinosad $0.015 \%$ (272.33 q/ha), followed by Imidacloprid $0.005 \%$ (250.88 q/ha), Neem oil 2.5ml/l (185.70 q/ha), NSKE 5\% (165.65 q/ha) and Garlic sap extract (142.32 q/ha), Pongima oil (192.62), Beauveria bassiana (133.80) as compared to control $\mathrm{T}_{\mathrm{o}}$ (95.54 $\mathrm{q} /$ ha). When the cost-benefit ratio was worked out, an interesting result was achieved. Among the treatment studied, the best and most economical treatment was Spinosad $0.015 \%$ (1:11.36) followed by Imidacloprid $0.005 \%$ (1:10.88), Pongamia oil (1:8.19), Neem oil 2.5ml/1 (1:7.92), NSKE 5\% (1:6.52) and Garlic sap extract (1:5.69), Beauveria bassiana (1:5.30)as compared to control $\mathrm{T}_{\mathrm{O}}$ (1:3.74) Vanisree et al.,(2013) and Vijaya et al., (2016). They reported that Spinosad was found most effective in reducing the population of Scirtothrips dorsalis as well as in increasing yield. Among all the treatment Spinosad $0.015 \%$ proved to be the best treatment followed by Imidacloprid $0.005 \%$, Pongamia oil, Neem oil $2.5 \mathrm{ml} / 1$, NSKE 5\% and Garlic sap extract, Beauveria bassiana also effective in managing Scirtothrips dorsalis reduction. Recommended dose of biopesticides may be useful in devising proper integrated pest management strategy against chilli thrips.

\section{References}

Choudhary, B.R. and Fageria, S. (2009). A text book on production technology of vegetables (Kalyani publishers). 2: pp $66-67$.

Henderson, C.F and Tilton, E.W. (1995). Tests with the acaricides against the brown wheat mite. J.of Eco. Entomology 48: 157- 161

Kumar, S. D.; Haseeb Masarrat and Qamar Muntaha. (2012). Comparative potential of different botanicals and synthetic insecticides and their economics against Leucinodes orbonalis in eggplant. J. of Plant Prot. Res. 52(1): 35-39.

Larral, P. and Ripa, R. (2007). Evaluation of pesticide effectiveness on the control of heliothrips haemorrhoidalis (Thysanoptera: Thripidae) on avocado threes Persea Americana mill Proceedings VI World avocado 
congress (Actas VI congress mundial Del aguacate). Vine Del Mar, Chile. 13 (8) $978-956$.

Mondal, B. and Mondal, P. (2012). Ecofriendly pest management practices for leaf curl complex of chilli Capsicum annum (L.). Biopest, (supplementary) 4: $115-118$.

Patel, B.H.; Koshiya, D.J.; Korat, D.M. and Vaishnav, P. R. (2009). Evaluation of some insecticides against chilli thrips Scirtothrips dorsalis (Hood) Karnataka J. Agri. Sci., 22 (2): 327-33

Reddy A. V. and Sreehari G. (2009). Studies on efficacy of fipronil $80 \mathrm{WG}$ a new formulation and other chemicals against Chilli thrips. Int. J. of agri. Sci. Vol. 5 $140-141$.

Rai, M. And Pandey, A. K. (2007). Towards a rainbow revolution. The Hindu Survey of Indian Agriculture. Pp.112-119.

Seal, D. R. and Kumar, V. (2010) Biological response of chilli thrips, Scirtothrips dorsalis (Hood) (Thysanoptera: Thripidae), to various regimes of chemical and biorational insecticides. Crop Prot. 29 (11): 1241-1247.
Seal, D. R.; Ciomperlik, M.; Richards, M. L.; and Klassen, W. (2006). Comparative effectiveness of chemical insecticides against the chilli thrips, Scirtothrips dorsalis (Hood) (Thysanoptera: Thripidae), on pepper and their compatibility with natural enemies. Crop Prot. 25: 949 - 955.

Tommasini, M.G. and Ceredi, G. (2007). Damages on nectarines by thrips in northern Italy: monitoring and control on late attacks. Bulletin of Insectology. 60 (1): 71-75.

Vanisree, K.; Upendhar, S.; Rajasekhar, P.; Ramachandra, G.; Rao and Srinivasa Rao (2013). Field evaluation of certain newer insecticides against Chilli thrips, Scirtothrips dorsalis (Hood).Sci. park Res. J. 1 (20):1-13

Vijaya, L.P.; Vijaya, L. T.; Naram, N.L. and Venkata R. C. (2016). Field evaluation of certain new insecticides for the management of chilli thrips in Andhra Pradesh Ind. J. of Plant Prot. 44 1:4952.

\section{How to cite this article:}

Rakesh Kumar Meena and Anoorag R. Tayde. 2017. Field Efficacy of Certain Bio-Pesticides against Chilli Thrips Scirtothrips dorsalis (HOOD) on Chilli (Capsicum aпnиum L.). Int.J.Curr.Microbiol.App.Sci. 6(6): 2188-2192. doi: https://doi.org/10.20546/ijcmas.2017.606.258 